Фармакологічні дослідження біологічно активних речовин

Pharmacological researches of biologically active substances

Рекомендована д. мед. наук, проф. С. І. Климнюком

УДК 615.322:576.8.097.5:[612.017.1:616-008

\title{
ВПЛИВ ГРИБА GANODERMA LUCIDUM (CURT.:FR.) P. KARST. HA ГУМОРАЛЬНУ ІМУННУ ВІДПОВІДЬ У МИШЕЙ ЛІНІЇ СВА/СА З ВТОРИННИМ ІМУНОДЕФІЦИТОМ
}

\author{
СВ. Т. Підченко ${ }^{1}$, І. В. Ніженковська ${ }^{1}$, Н. Г. Бичкова ${ }^{1}$, Н. А. Бісько르, А. Є. Родніченко \\ ${ }^{1}$ Національний медичний університет імені О. О. Богомольця \\ ${ }^{2}$ Інститут ботаніки імені Н. Г. Холодного НАН України, Київ

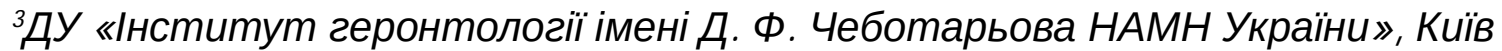

\begin{abstract}
Резюме: у статті представлені результати досліджень впливу порошку біомаси гриба Ganoderma lucidum на показники гуморальної імунної відповіді в мишей лінії СВА/Са в умовах модельованого вторинного імунодефріциту. Для моделювання імунодефіциту використовували імуносупресант циклофросфамід, який вводили одноразово в дозі 150 мг/кг, внутрішньочеревно, в перший день експерименту. Результати проведеного дослідження показують, що застосування порошку біомаси гриба Ganoderma lucidum мишам лінії CBA/Са 3 індукованою імунною недостатністю викликає достовірне зростання кількості антитілоутворювальних клітин у селезінці та рівня антитіл у сироватці крові.
\end{abstract}

Ключові слова: гриб Ganoderma lucidum, гуморальна імунна відповідь, циклофросфамід, імунодефріцит.

Вступ. Пошук та розробка лікувальнопрофрілактичних засобів природного походження $€$ актуальною проблемою сьогодення. В останні десятиріччя базидіальні гриби та біологічно активні речовини, виділені з них, привертають велику увагу вчених країн Азії та Північної Америки. Ganoderma lucidum (трутовик лакований) - відомий базидіальний гриб, який використовується протягом майже 2 тисяч років у Китаї, Японії та Кореї для запобігання та лікування бронхіту, хронічного гепатиту, гіпертензії, атеросклерозу, онкологічних захворювань та імунологічних порушень. Вченими були виділені біологічно активні речовини з гриба Ganoderma lucidum, зокрема тритерпеноїди, полісахариди, стероїди, алкалоїди та амінокислоти, які розглядаються як перспективні речовини для створення лікувально-профілактичних засобів для лікування різних захворювань $[8,16]$. Як діючу субстанцію при дослідженні фрармакологічних властивостей гриба Ganoderma lucidum зазвичай використовуються екстракти 3 плодових тіл гриба, рідше - міцелію та спор. На сьогодні майже все світове виробництво Ganoderma lucidum базується на екстенсивному методі культивування. Його проводять на свіжозрубаних обрубках різних видів твердих порід дерев. Вирощування плодових тіл таким способом займає від 3 до 5 місяців. Переваги глибинного культивування полягають у скороченні виробничого циклу до 2-3 тижнів, більш високій та стабільній урожайності, вирощуванні протягом всього року, завдяки створенню оптимальних умов, необхідних для отримання біомаси, можливості застосування механізації й автоматизації технологічних процесів [6]. Не вивченим залишається вплив біомаси гриба Ganoderma lucidum, вирощеної методом глибинного культивування на різ- ні ланки імунітету при імунодесріцитних станах. Тому метою нашого дослідження було визначення впливу порошку біомаси гриба Ganoderma lucidum на гуморальну імунну відповідь у мишей в умовах модельованого вторинного імунодесріциту in vivo.

Методи дослідження. Біомаса гриба Ganoderma lucidum була вирощена методом глибинного культивування на базі Інституту ботаніки імені Н. Г. Холодного НАН України (м. Київ) під керівництвом доктора біологічних наук відділу мікології Н. А. Бісько. Біомаса гриба була висушена та подрібнена до порошкового стану.

Для моделювання імунодесріциту використовували імуносупресант циклофросрамід (ЕНДОКСАН - «Baxter Oncology GmbH», Німеччина), який вводили одноразово дозою 150 мг/кг, внутрішньочеревно, в перший день експерименту. Циклофросфамід належить до антинеопластичних засобів та має цитотоксичну, протипухлинну та імуносупресивну активність. Після ін'єкції циклофросфраміду мишам протягом 10 днів вводили порошок біомаси гриба Ganoderma lucidum перорально у дозі з розрахунку 0,01 мг на 20 гр маси тіла (0,5мг/кг). У попередній серії наших досліджень при застосуванні цієї дози спостерігався найбільш виразний стимулюючий ефект на імунну відповідь [13]. Як референтний препарат використовували імунотропний препарат ехінацея (ЕхінацеяАстрафрарм, Україна). Дозу рефрерентного препарату розраховували з використанням коефіцієнта, який визначає співвідношення між дозами лікарських засобів для людини і різних видів експериментальних тварин. Для миші він дорівнює 387,9.

Дослідження проводили на статевозрілих (віком 3-5 міс.) мишах-самцях лінії СВА/Са. Тварини були розподілені на 4 групи: 1 - контрольні миші;

ISSN 2312-0967. Фармацевтичний часопис. 2015. № 2 
Фармакологічні дослідження біологічно активних речовин

Pharmacological researches of biologically active substances

2 - миші, яким вводили циклосросфамід;

3- миші, які після введення циклофоосраміду отримували порошок біомаси гриба Ganoderma lucidum;

4 - миші, які після введення циклофросораміду отримували ресрерентний препарат ехінацея.

Вплив біомаси гриба Ganoderma lucidum на гуморальну імунну відповідь вивчали шляхом визначення числа антитілоутворювальних клітин (АУК) і титрів антитіл у сироватці крові. Тварин імунізували еритроцитами барана внутрішньочеревно в дозі $2,5 \cdot 10^{8}$ клітин на мишу (0,2 мл 3 \% завису еритроцитів барана на фрізіологічному розчині). Дослідних тварин забивали на 5-у добу після ін'єкції. Для евтаназії мишей застосовували передозування ефріру медичного для наркозу [4]. Результати представляли у вигляді кількості антитілоутворювальних клітин на $10^{6}$ клітин або абсолютної кількості АУК в перерахунку на загальну кількість клітин в органі [9]. Для визначення титрів гемолізинів і гемаглютинінів у сироватці крові після проведення процедури евтаназії тварин проводили процедуру забору крові з орбітального синусу шляхом енуклеації. Результати визначення гемолізинів і гемаглютинінів представляли в одиницях - $\log _{2}$ [12]. Підрахунок загальної кількості клітин проводили у камері Горяєва 3 використанням 3 \% оцтової кислоти, що дозволяє вилучити з обліку еритроцити [2]. Відносну масу тимусу та селезінки розраховували як відсоток співвідношення маси тимуса або селезінки до маси тіла. Індекс заселення лімфоїдними клітинами тимусу та селезінки розраховували як співвідношення кількості клітин в органі до маси органа.

Статистичний аналіз результатів проводили за допомогою t-критерію Стьюдента [1, 3].

Результати й обговорення. Як видно з даних таблиці 1, введення циклофоссраміду призвело до вірогідного зниження маси тіла мишей, різкого зниження маси тимусу, відносної маси тимусу, індексу заселення лімфоїдними клітинами тимусу, кількості лімфоӧдних клітин в тимусі, кількості ядровмісних клітин в стегновій кістці та індексу заселення лімфоїдними клітинами селезінки. Імунодепресанти першого покоління, до яких належить циклофросфрамід, пошкоджують всі клітини, які діляться, у тому числі лімфоцити. Вони порушують процеси гемопоезу, оновлення тканин, спричиняють спустошення лімфоїдної тканини, пригнічують всі фрорми імунної відповіді.

Слід зазначити, що в наших дослідженнях на фоні застосування циклофоосфаміду маса селезінки, відносна маса селезінки та кількість лімфоїдних клітин в органі вірогідно зростала порівняно 3 контрольними мишами (табл. 1). Рівень первинної імунної відповіді різко знижувався в умовах введення циклофоосфаміду. Показник, який найбільшою мірою відображає активність гуморального імунітету - здатність до продукції АУК в селезінці у відповідь на введення антигену. Так, відносна та абсолютна кількість АУК в селезінці знижувалася в 4,7 та 3,5 раза, відповідно (рис. 1 та 2). Як видно $з$ даних рисунків 3 та 4, рівень антитіл в сироватці крові знижувався порівняно 3 даними в групі контрольних мишей в 9,3 раза (титр гемолізинів) та в 2,5 раза (титр гемаглютинінів). Циклосроссрамід виступає інгібітором антитілопродукції у мишей, імунізованих еритроцитами барана - тимусзалежним антигеном.

Як показали проведені нами дослідження щодо характеристики лімсооїних органів (табл. 1), відновлення, причому на застосування як досліджуваного засобу, так і ресрерентного препарату, спостерігалося тільки для такого показника, як кількість ядровмісних клітин у стегновій кістці. Значення цього показника після застосування обох препаратів було вірогідно вище порівняно з даними в групі мишей, які отримували циклосроссрамід, та вище, ніж в групі контрольних мишей (табл. 1). Відновлення показників маси тимуса, відносної маси тимуса, індексу заселення тимуса та кількості лімооӧдних клітин в органі до рівня даних в групі контрольних мишей після застосування обох препаратів в умовах введення імуносупресанту циклофоссраміду виявлено не було. Можливо, це пов'язано з тим, що відновлення Т-лімсроцитів відбувається повільніше або/та курсове застосування протягом 10 діб порошку біомаси гриба Ganoderma lucidum та контрольного препарату є недостатнім для відновлення порушень, викликаних циклосросфрамідом у центральному органі імунної системи - тимусі.

Збільшення кількості ядровмісних клітин вірогідно можна пояснити тим, що вченими Zhang et al., 2002 [5], було виділено протеоглікан з плодових тіл гриба Ganoderma lucidum, який стимулював проліферацію, диференціацію та активацію В-лімфоцитів у мишей. Було встановлено, що при взаємодії з цим протеогліканом В-клітини мишей збільшувалися в розмірах, на їх поверхні збільшувалась кількість маркерів активації лімфоцитів CD71 та CD25, а також збільшувався рівень секреції імуноглобулінів. Протеоглікан збільшував експресію протеїнкіназ Са та Су в В-клітинах. Також відмічалося незначне збільшення продукції інтерлейкіна-2 в лімфоцитах, при цьому продукція інтерлейкіну-4 та рівень внутрішньоклітинного $\mathrm{Ca}^{2+}$ не змінювались [5].

В інших дослідах було показано, що полісахаридна фрракція Ganoderma lucidum спричиняє активацію В-клітин селезінки мишей, а також їх дифреренціацію в плазматичні клітини, які секретують імуноглобулін М. Ця полісахаридна фрракція індукує білок - регулятор плазмо-клітинного диференціювання $[10,11]$.

Як відомо, В-лімфроцити відіграють важливу роль у гуморальній імунній відповіді, продукуючи антитіла проти антигенів. Вони також виступають в ролі антигенпрезентуючих клітин, а також перетворюються в клітини пам'яті після взаємодії 3 антигеном [5, 7]. Дослідження впливу порошку біомаси гриба Ganoderma lucidum на гуморальну імунну відповідь мишей лінії CBA на еритроцити барана в умовах введення ци-

ISSN 2312-0967. Pharmaceutical review. 2015. № 2 
Фармакологічні дослідження біологічно активних речовин

Pharmacological researches of biologically active substances

\begin{tabular}{|c|c|c|c|c|}
\hline 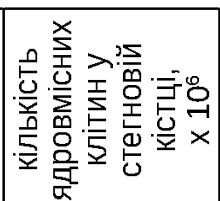 & 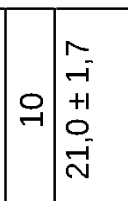 & 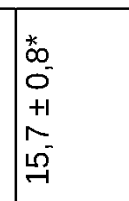 & 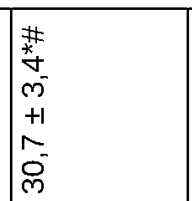 & 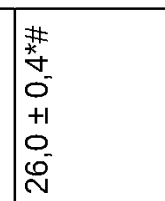 \\
\hline 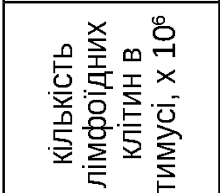 & 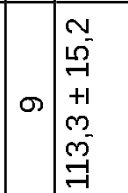 & 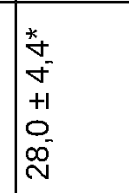 & $\begin{array}{l}* \\
\infty \\
o \\
+ \\
+1 \\
0 \\
0 \\
\alpha \\
N\end{array}$ & 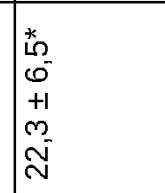 \\
\hline 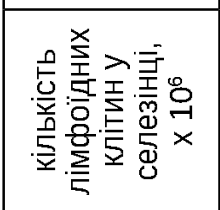 & 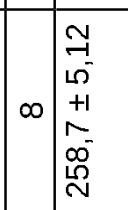 & 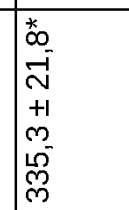 & 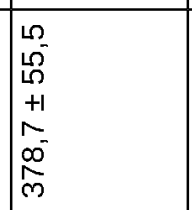 & 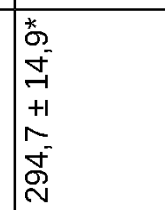 \\
\hline 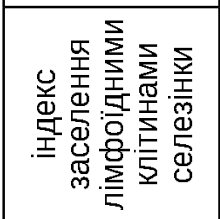 & 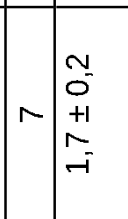 & $\mid \begin{array}{l}* \\
*-1 \\
0 \\
0 \\
+1 \\
m-1 \\
-i\end{array}$ & $\begin{array}{l}-1 \\
0 \\
+1 \\
+1 \\
+1 \\
-1\end{array}$ & 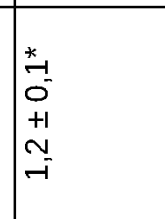 \\
\hline 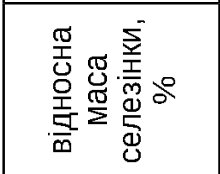 & $\mid \begin{array}{l}0 \\
0 \\
0 \\
0 \\
0 \\
01 \\
0 \\
0\end{array}$ & $\begin{array}{l}* \\
* \\
0 \\
0 \\
+1 \\
-1 \\
-1\end{array}$ & $\begin{array}{l}* \\
*-1 \\
0 \\
+1 \\
-1 \\
-1\end{array}$ & $\begin{array}{l}* \\
0 \\
0 \\
0 \\
0 \\
0+1 \\
0 \\
0 \\
-1\end{array}$ \\
\hline 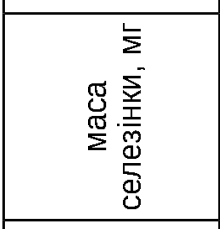 & 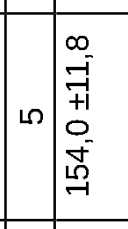 & 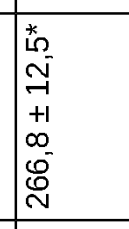 & 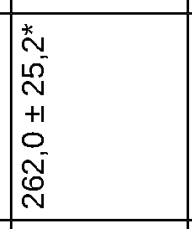 & 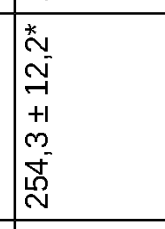 \\
\hline 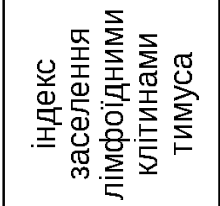 & $+\mid \begin{array}{l}0 \\
m \\
0 \\
+1 \\
0 \\
\infty \\
N\end{array}$ & 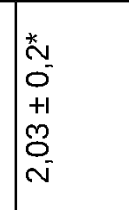 & $\mid \begin{array}{l}-1 \\
0 \\
+1 \\
n \\
n \\
n\end{array}$ & 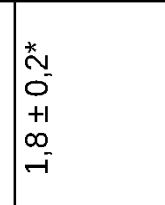 \\
\hline 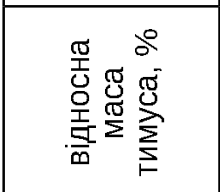 & $m \mid \begin{array}{l}\tilde{N} \\
0 \\
0 \\
+1 \\
0 \\
0 \\
0 \\
0\end{array}$ & $\begin{array}{l}* \\
0 \\
0 \\
0 \\
+1 \\
0 \\
0 \\
0\end{array}$ & $\begin{array}{l}* \\
0 \\
0 \\
0 \\
0 \\
+1 \\
0 \\
0 \\
0 \\
0\end{array}$ & $\mid \begin{array}{l}* \\
0 \\
0 \\
0 \\
+1 \\
+1 \\
00 \\
0 \\
0\end{array}$ \\
\hline 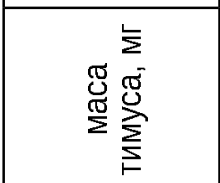 & 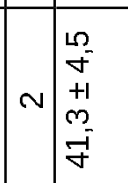 & 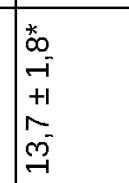 & 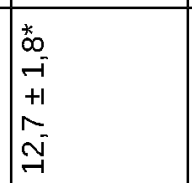 & 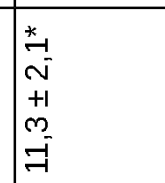 \\
\hline 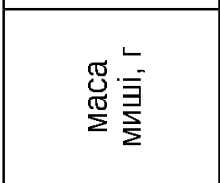 & 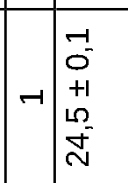 & $\begin{array}{l}* \\
0 \\
0 \\
0 \\
+1 \\
N \\
\tilde{N} \\
\text { N }\end{array}$ & 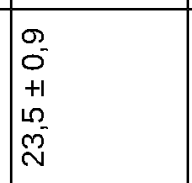 & $\begin{array}{l}* \\
+ \\
0 \\
0 \\
+1 \\
m \\
\infty \\
N\end{array}$ \\
\hline 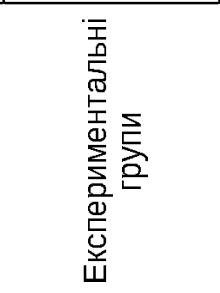 & 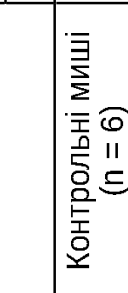 & 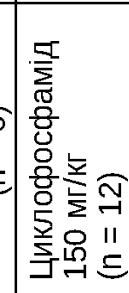 & 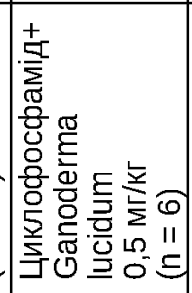 & 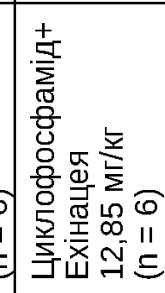 \\
\hline
\end{tabular}

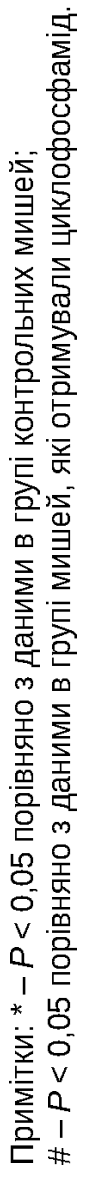

ISSN 2312-0967. Фармацевтичний часопис. 2015. № 2 
Фармакологічні дослідження біологічно активних речовин

Pharmacological researches of biologically active substances

клофроссраміду виявило, що він здатний відновлювати відносну кількість АУК клітин в селезінці на рівні референтного препарату, про що свідчить статистично достовірне збільшення відносної кількості АУК в селезінці у 2 рази порівняно з групою мишей, які отримували циклофоссрамід. Проте відновлення до показників контрольної групи мишей не спостерігалось (рис.1).
Застосування порошку біомаси гриба в умовах введення циклофроссраміду також спричиняло статистично достовірне збільшення абсолютної кількості АУК в селезінці в 2,1 раза порівняно з групою мишей, які отримували циклофоссрамід, причому ресрерентний препарат збільшував абсолютну кількість АУК в селезінці лише в 1,6 раза (рис. 2). Дані результати

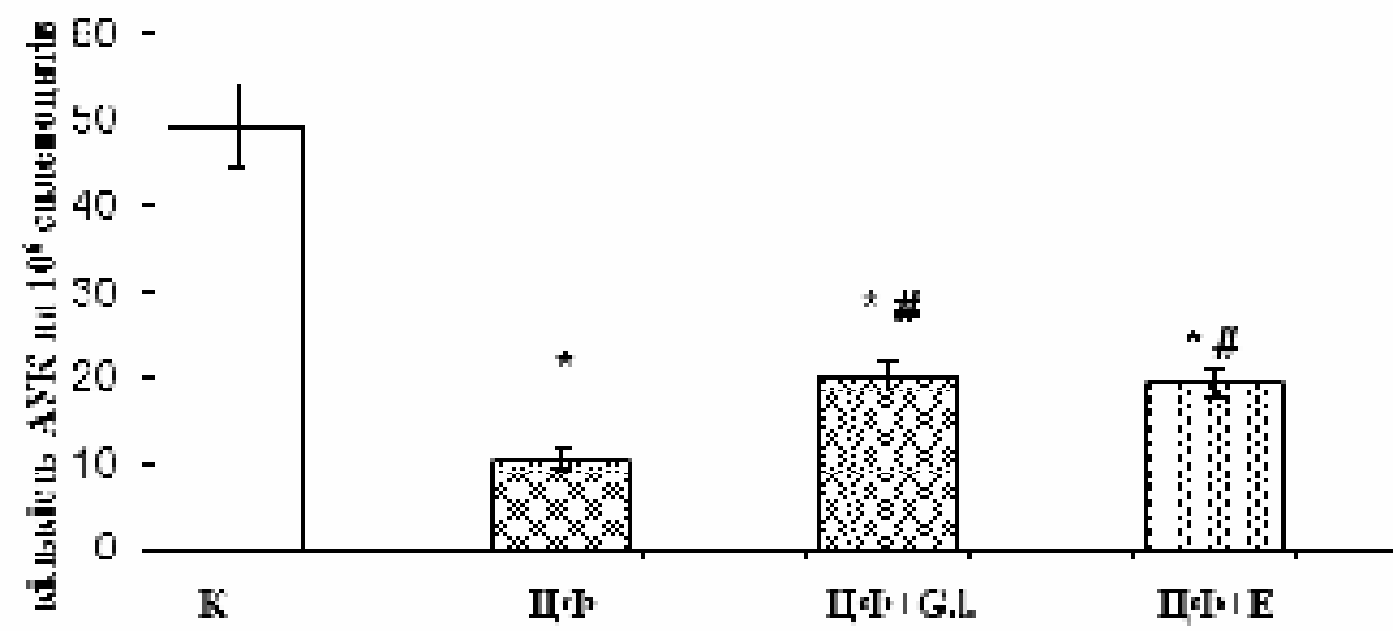

Рис. 1. Відносна кількість АУК в селезінці у відповідь на застосування порошку біомаси гриба Ganoderma lucidum в умовах введення імуносупресанту: К - контрольна група мишей; ЦФ - група мишей, які отримували внутрішньочеревно імуносупресант у дозі 150 мг/кг; ЦФ+G.I. - група мишей, які після ін'єкції імуносупресанту отримували гриб Ganoderma lucidum; ЦФ+Е - група мишей, які після ін'єкції імуносупресанту отримували

Примітки: ресрерентний препарат ехінацеї.

* $-P<0,05$ порівняно $з$ даними в групі контрольних мишей;

\# $-P<0,05$ порівняно з даними в групі мишей, які отримували циклофосфамід.

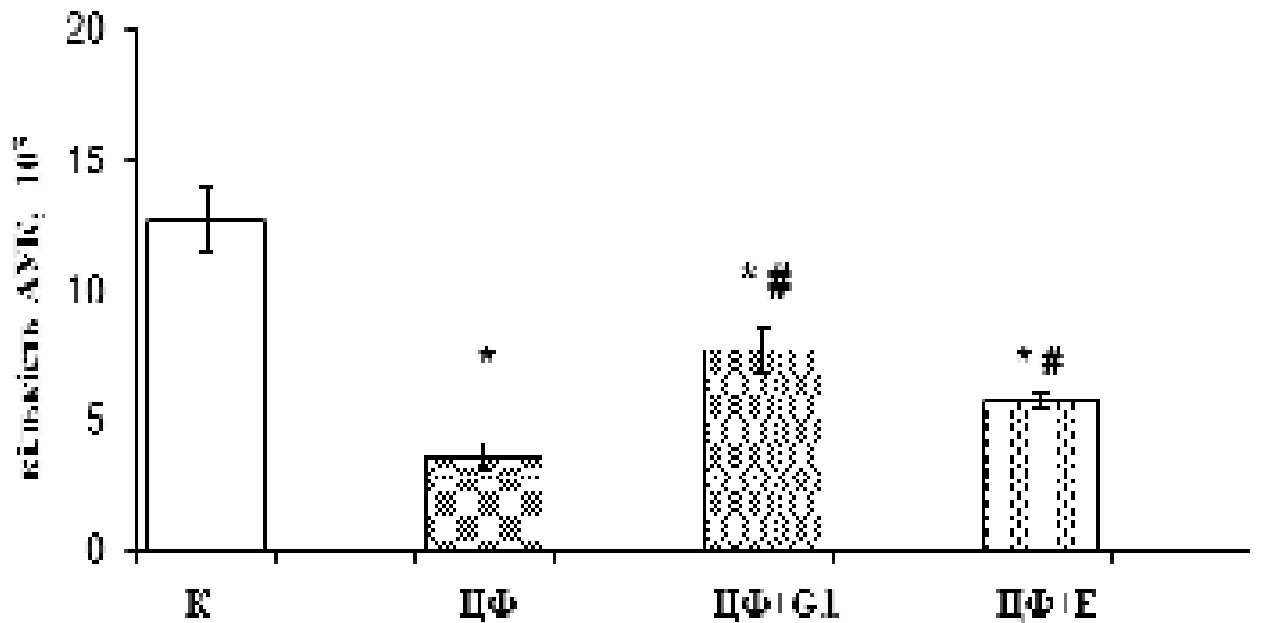

Рис. 2. Абсолютна кількість АУК в селезінці у відповідь на застосування порошку біомаси гриба Ganoderma lucidum в умовах введення імуносупресанту: К - контрольна група мишей; ЦФ - група мишей, які отримували внутрішньочеревно імуносупресант у дозі 150 мг/кг; ЦФ+G.І.- група мишей, які після ін'єкції імуносупресанту отримували гриб Ganoderma lucidum; ЦФ+Е - група мишей, які після ін'єкції імуносупресанту отримували контрольний препарат ехінацеї.

Примітки:

1. * $-P<0,05$ порівняно 3 контрольною групою мишей;

$\#-P<0,05$ порівняно з даними в групі мишей, які отримували циклофоосфамід.

ISSN 2312-0967. Pharmaceutical review. 2015. № 2 
Фармакологічні дослідження біологічно активних речовин Pharmacological researches of biologically active substances

можуть свідчити про імуномодулювальний вплив біомаси гриба Ganoderma lucidum на гуморальний імунітет у мишей в умовах введення імуносупресанта.

Введення порошку біомаси гриба Ganoderma lucidum на фроні циклофосфраміду підвищувало рівень антитіл в сироватці крові порівняно 3 групою мишей, які отримували циклофросфамід. При цьому титр гемолізинів збільшився на рівні рефрерентного препарату в 6,7 раза, відновившись майже до рівня контрольної групи мишей. Титр гемаглютинінів збільшився у 2,4 раза, відновившись до рівня контрольної групи мишей, при цьому препарат ехінацеї показав збільшення цього показника в 2,2 раза (рис. 3,4 ). B роботі Bao et al. методом іонного обміну та гельфрільтраційної хроматографрії з плодових тіл гриба Ganoderma lucidum було виділено 3 полісахариди,
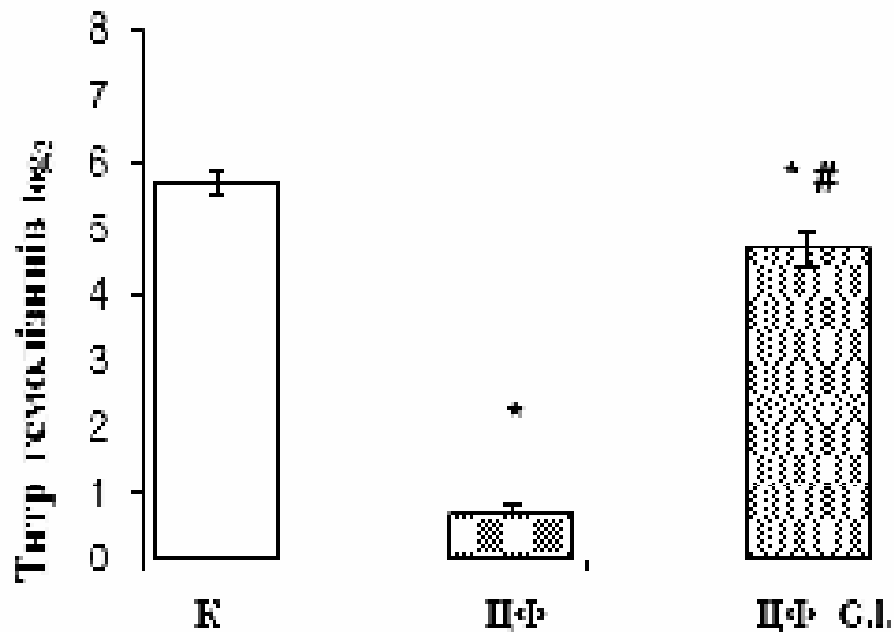

I:Ir G.I,

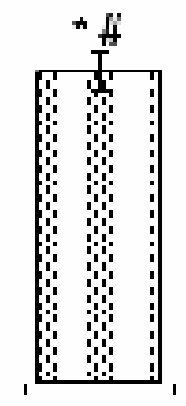

Пт्म $\mathbf{E}$

Рис. 3. Титр гемолізинів у сироватці крові мишей у відповідь на застосування порошку біомаси гриба Ganoderma lucidum в умовах введення імуносупресанту: К - контрольна група мишей; ЦФ - група мишей, які отримували внутрішньочеревно імуносупресант у дозі 150 мг/кг; ЦФ+G.І. - група мишей, які після ін'єкції імуносупресанту отримували гриб Ganoderma lucidum; ЦФ+Е - група мишей, які після ін'єкції імуносупресанту отримували ресрерентний препарат ехінацеї.

Примітки:

* - $P<0,05$ порівняно $з$ даними в групі контрольних мишей;

$\#-P<0,05$ порівняно з даними в групі мишей, які отримували циклофоосфамід.

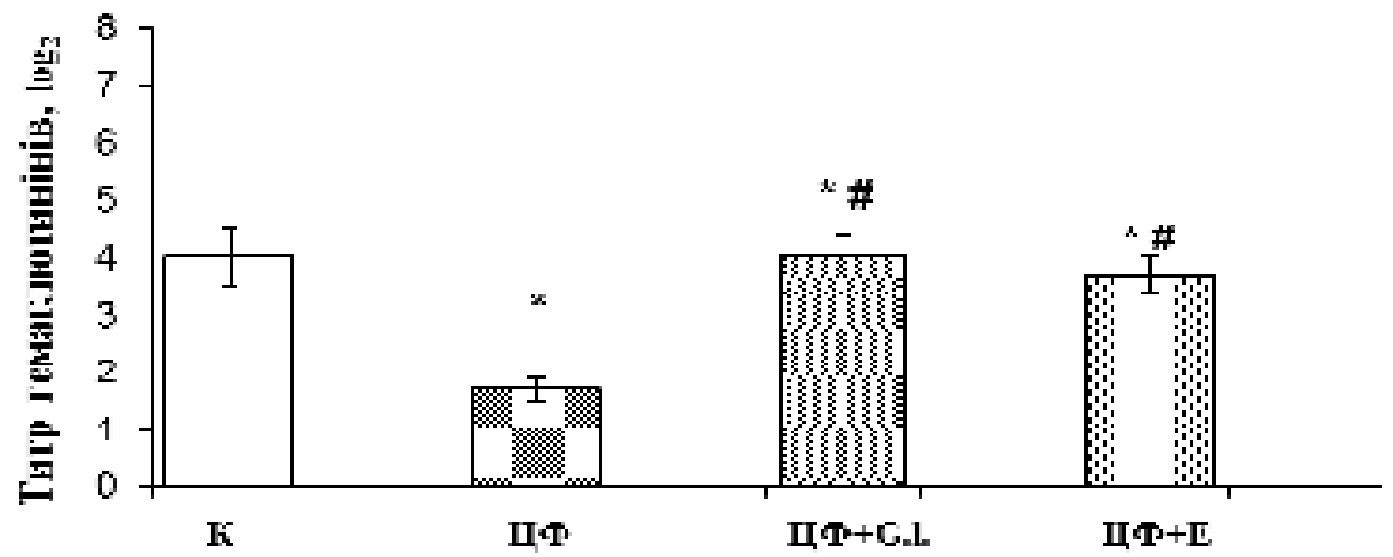

Рис. 4. Титр гемаглютинінів у сироватці крові мишей у відповідь на застосування порошку біомаси гриба Ganoderma lucidum в умовах введення імуносупресанту: К - контрольна група мишей; ЦФ - група мишей, які отримували внутрішньочеревно імуносупресант у дозі 150 мг/кг; ЦФ+G.I. - група мишей, які після ін'єкції імуносупресанту отримували гриб Ganoderma lucidum; ЦФ+Е - група мишей, які після ін'єкції імуносупресанту

Примітки: отримували референтний препарат ехінацеї.

* $-P<0,05$ порівняно з даними в групі контрольних мишей;

\# - $P<0,05$ порівняно з даними в групі мишей, які отримували циклофосфамід.

ISSN 2312-0967. Фармацевтичний часопис. 2015. № 2 
2 гетероглікани (PL-1 та PL-4) та 1 глюкан (PL-3), які збільшували проліферацію Т- і В-лімфоцитів in vitro. Подальші дослідження показали, що полісахарид PL-1 також здатний стимулювати продукування антитіл у мишей [16]. Збільшення рівня антитіл в нашому експерименті може бути пояснене саме вмістом цих біологічно активних речовин і в біомасі гриба Ganoderma lucidum, вирощеної методом глибинного культивування.

Збільшення абсолютної та відносної кількості АУК у селезінці та рівня антитіл в сироватці крові, ймовірно, пов'язане з тим, що біомаса гриба Ganoderma lucidum також містить полісахариди, зокрема $\beta-D-$ глюкани, які нещодавно були виділені з плодових тіл гриба $[7,8,14,16]$. Ці полісахариди розглядаються як перспективні імуномодулятори, оскільки в результаті досліджень останніх років було відкрито рецептори $\beta$-D-глюкану на поверхні білих кров'яних клітин (лейкоцитів, моноцитів, макрофрагів та інших лімороцитів) у тварин і людей, а саме toll-like рецептори. Полісахарид, виділений з водного екстракту плодових тіл Ganoderma lucidum, проявляв здатність зв'язуватися 3 поверхнею клітин імунної системи (макрофрагів та В-лімфоцитів) за допомогою toll-like рецептора TLR-4, що може призводити до каскаду реакцій, в тому числі до підвищення експресії iPHK Blimp-1 та подальшого дозрівання В-лімфоцитів. Полісахаридна фрракція також здатна підвищувати рівень секреції антитіл в периферичних В-лімфоцитах, пов'язаної 3 індукцією іРНК головного регулятора плазматичного дифреренціювання Blimp-1 [14].

Низька цитотоксичність гриба Ganoderma lucidum та його можлива ефективність в лікуванні імуноло- гічних порушень робить його перспективною сировиною для розробки лікувальних засобів для лікування онкологічних хворих, які проходять курс хіміотерапії та / або променевої терапії, шляхом підвищення стану імунної системи та фрунціональних і кількісних параметрів імунної системи та зменшення токсичності $[8,15,17]$.

Таким чином, результати проведеного дослідження показують, що застосування порошку біомаси гриба Ganoderma lucidum мишам лінії CВА/Са з індукованою імунною недостатністю викликає достовірне зростання кількості АУК у селезінці та рівня антитіл в сироватці крові, що може свідчити про імуномодулювальний вплив порошку біомаси гриба Ganoderma lucidum на гуморальну імунну відповідь.

Висновки. 1. При експериментальному імунодефріциті введення порошку біомаси гриба Ganoderma lucidum протягом 10 днів мишам лінії CBA/Са викликає достовірне збільшення кількості ядровмісних клітин в стегновій кістці. Відновлення показників маси тимуса, відносної маси тимуса, індексу заселення тимуса та кількості лімсроїдних клітин в органі до рівня даних у групі контрольних мишей після застосування як біомаси гриба, так і референтного препарату в умовах введення імуносупресанту циклофоссраміду виявлено не було.

2. Застосування порошку біомаси гриба Ganoderma lucidum мишам лінії CBA/Са з індукованою імунною недостатністю викликає достовірне зростання кількості АУК в селезінці та рівня антитіл в сироватці крові, що може свідчити про імуномодулювальний вплив порошку біомаси гриба Ganoderma lucidum на гуморальну імунну відповідь.

\section{Література}

1. Гублер Е. В. Применение непараметрических критериев статистики В медико-биологических исследованиях / Е. В. Гублер, А. А. Генкин. - Л. : Медицина, 1973. - 141 с.,

2. Лимсроциты. Методы / под. ред. Дж. Клауса; пер. с англ.. - М. : Мир, 1990. - 395 с.

3. Минцер О. П. Методы обработки медицинской информации / О. П. Минцер, Б. Н. Угаров, В. В. Власов. - К. : Вища школа, 1991. - 271 с.

4. Эвтаназия экспериментальных животных / Методические рекомендации по выведению животных из эксперимента. - М. : М3 СССР, 1985. - 13 c.

5. Activation of B lymphocytes by GLIS, a bioactive proteoglycan from Ganoderma lucidum / J. Zhang, Q. Tang, M. Zimmerman-Kordmann [et.al] // Life Sciences - 2002. Vol.71. - P. 623-638.

6. Current techniques for the cultivation of Ganoderma lucidum for the product of biomass, ganoderic acid and polysaccharides / R. Wagner, D. A. Mitchell, G. L. Sassaki [et al.] // Food Technology and Biotechnology. - 2003. Vol.41, №4. - P. 371-382.

7. Ganoderma lucidum Polysaccharides: Immunomo-

dulation and Potential Anti-Tumor Activities / Z. Xu, X. Chen, Z. Zhong [et al.] // The American Journal of Chinese Medicine. - 2011. - Vol. 39, №1. - P. 15-27.

8. Ganoderma lucidum and its pharmaceutically active compounds / B. Boh, M. Berovic, J. Zhang [et al.] // Biotechnology Annual Review. - 2007. - Vol. 13. - P. 265301.

9. Jerne N. K. Cell-bound antibodies / N. K. Jerne, A. A. Nordin, C. Henry. - Wistar Institute Press. - 1963. $109 \mathrm{p}$.

10. Lin, Z. B. Cellular and molecular mechanisms of immuno-modulation by Ganoderma lucidum / Z. B. Lin // Journal of Pharmacological Sciences - 2005. - Vol. 99. P. 144-153.

11. Lin, Z. B. Anti-tumor and immunoregulatory activities of Ganoderma lucidum and its possible mechanisms I Z. B. Lin, H. N. Zhang, // Acta Pharmacologica Sinica 2004. - Vol. 25, № 11. - P. 1387-1395.

12. McGregor D. D. The antibody response of rats depleted of lymphocytes by chronic drainage from the thoracic duct / D. D. McGregor, J. L. Gowas // Journal of Experimental Medicine - 1963. - Vol. 118. - № 2. - P. 303-320.

ISSN 2312-0967. Pharmaceutical review. 2015. № 2 
Фармакологічні дослідження біологічно активних речовин Pharmacological researches of biologically active substances

13. Pidchenko V. T. The effect of different doses of biomass powder of Ganoderma lucidum (Curt.: Fr.) P. Karst. on humoral immune response in mice line CBA/ Ca / V. T. Pidchenko // Proceedings of the 3rd European Conference on Biology and Medical Sciences: Vienna, 28 october, 2014. P. 211-219.

14. Reishi polysaccharides induce immunoglobulin production through the TLR4/TLR2 mediated induction of transcription factor Blimp-1 / K. I. Lin, Y. Y. Kao, H. K. Kuo [et al.] // Journal of Biological Chemistry. - 2006. - Vol. 281. № 34. - P. 2411-2423.
15. Safety and tolerability of Ganoderma lucidum in healthy subjects: a double-blind randomized placebo-controlled trial I S. M. Wicks, R. Tong, C. Z. Wang, [et. Al] American Journal of Chinese Medicine. - 2007. - Vol. 35. - P. 407-414.

16. Structural features of immunologically active polysaccharides from Ganoderma lucidum / X. F. Bao, X. S. Wang, Q. Dong, [et al.] // Phytochemistry. - 2002. Vol. 59. - P. 175-181.

17. Yuen J. W. Anticancer effects of Ganoderma lucidum: a review of scientific evidence / J. W. Yuen, M. D. Gohel // Nutrition and Cancer - 2005. - Vol. 53 - P. 11-17.

\title{
ВЛИЯНИЕ ГРИБА GANODERMA LUCIDUM (CURT.:FR.) P. KARST. НА ГУМОРАЛЬНЫЙ ИМУННЫЙ ОТВЕТ У МЫШЕЙ ЛИНИИ СВА/СА С ВТОРИЧНЫМ ИММУНОДЕФИЦИТОМ
}

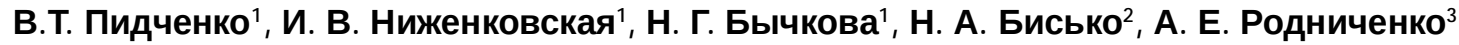 \\ ${ }^{1}$ Национальный медицинский университет имени А. А. Богомольца \\ ${ }^{2}$ Институт ботаники имени Н. Г. Холодного НАН Украины, Киев

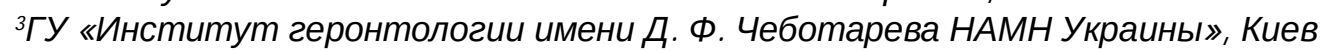

Резюме: в статье представлены результаты исследований влияния порошка биомассы гриба Ganoderma lucidum на показатели гуморального иммунного ответа у мышей линии СВА/Са в условиях моделированного вторичного иммунодефицита. Для моделирования иммунодефицита использовали иммуносупресант циклофоссрамид, который вводили одноразово в дозировке 150 мг/кг, внутрибрюшинно, в первый день эксперимента. Результаты проведенного исследования показывают, что применение порошка биомассы гриба Ganoderma Lucidum мышам линии СВА/Са с индуцированной имунной недостаточностью вызывает достоверное увеличение количества антителообразующих клеток в селезенке и уровня антител в сыворотке крови.

Ключевые слова: гриб Ganoderma lucidum, гуморальный имунный ответ, циклофросфрамид, иммунодефицит.

\section{INFLUENCE OF MUSHROOM GANODERMA LUCIDUM (CURT.: FR.) P. KARST. ON THE HUMORAL IMMUNE RESPONSE IN MICE LINE CBA / CA WITH SECONDARY IMMUNODEFICIENCY}

\author{
V. T. Pidchenko ${ }^{1}$, I. V. Nizhenkovska ${ }^{1}$, N. H. Bychkova ${ }^{1}$, N. A. Bisko ${ }^{2}$, A. Ye. Rodnichenko ${ }^{3}$ \\ ${ }^{1}$ National Medical University by O. O. Bohomolets \\ ${ }^{2}$ Institute of Botany by M. H. Kholodnyi of NASU, Kyiv \\ ${ }^{3}$ State Institute of Gerontology by D. F. Chebotariov of NAMS of Ukraine, Kyiv
}

Summary: the article shows the results of the investigation of the influence of biomass powder of mushroom Ganoderma lucidum on the humoral immune response in mice line CBA / Ca in terms of the simulated secondary immunodeficiency. To simulate immunodeficiency was used the immunosuppressant cyclophosphamide, which was administered once a dose of $150 \mathrm{mg} / \mathrm{kg}$, intraperitoneally, the first day of the experiment. Results of the study show that the application of Ganoderma Lucidum biomass powder in mice line CBA / Ca with induced immune deficiency, causes a significant increase in the number of antibody-producing cells in the spleen and antibody levels in serum.

Key words: Ganoderma lucidum, humoral immune response, cyclophosphamide, immunodeficiency.

Отримано 07.04.2015

ISSN 2312-0967. Фармацевтичний часопис. 2015. № 2 